\title{
Water governance for sustainable irrigation: the role of civil society
}

\author{
H. Bjornlund ${ }^{1,2}$ \\ ${ }^{1}$ University of South Australia, Australia \\ ${ }^{2}$ University of Lethbridge, Canada
}

\begin{abstract}
How to share scarce water resources is one of the greatest challenges of the $21^{\text {st }}$ century and presents one of the greatest risks to global societies. Governments have found it problematic to resolve these complex issues using traditional top-down approaches. Many jurisdictions have therefore made a transition from government to governance in water management as this approach integrates all sectors of civil society in the process of finding solutions with minimum socioeconomic and environmental impacts, which are widely accepted within the affected communities. This process has proven difficult and conflict ridden in most places. Australia is one of the jurisdictions in which this process has been most aggressively promoted and therefore provides a good opportunity to learn lessons for other jurisdictions.

Keywords: sustainable irrigation, water sharing, Alberta, Canada, Australia.
\end{abstract}

\section{Introduction}

Traditionally water management and allocation has been the sole responsibility of governments following a centralized top-down approach. This approach was based on the supply management paradigm. If more water was needed, more resources was developed and allocated. Consequently, many water sources are now fully or over allocated and suffering environmental degradation as a result of current levels of extraction. In many instances the full impact of over-allocation is not yet felt as actual extraction is well below full allocation (e.g. within the South Saskatchewan River Basin (SSRB) in Alberta, Canada, only $50-60 \%$ of allocation is extracted). In many stressed basins this has raised serious concern as the pressure to increase 
extraction is mounting due to increases in population and economic activity. Water supply stress is one of the greatest future risks for global societies [1].

In response many jurisdictions are undergoing a paradigm shift from supply to demand management. To facilitate this a transition is also taking place from government to governance in water management $[2,3]$. This reflect the fact that water management is very complex and that changes to water allocation will cause socio-economic pain and community conflict. Hence, it is necessary to involve stakeholders, representing industry and citizens, in developing and implementing solutions, to ensure that they are as acceptable as possible to the affected communities.

This paper discusses these issues using examples from the Murray-Darling basin (MDB) in Australia where the transition from Government to Governance has been ongoing for the last decades. Water re-allocation to secure pressing environmental objectives has been pursued through planning processes involving collaboration between governments and key stakeholders with limited success. Water markets, where industry and citizen redistribute water between extractive users, and where mainly government and citizen secure water for the environment, have been more successful. This transition have changed the role of Government from making water allocation decisions towards improving the institutions and instruments that enable industry and citizen, to most effectively make these decisions while safeguarding socially and environmentally sustainable outcomes.

\section{The shift from government to governance}

As water scarcity intensifies and water quality deteriorates many governments stop issuing water entitlements to meet new demand. As a consequence water allocation and management becomes complex, wicked, and conflict ridden between individuals, institutions and jurisdictions alike. The top down supply driven approach becomes inappropriate, inadequate and politically undesirable. Water allocation becomes reallocation and the government have to take away from Paul to give to Peter. This typically comes at a high political cost.

It therefore becomes both necessary and politically more expedient to involve civil society in decision making in what has been known as governance processes to better understand the diversity and complexity of the issues and to identify solutions that are more likely to be accepted by the affected communities. Lautze et al. [4] argue that the governance approach has been adopted before it was fully developed and understood and consequently there are no standard definition, practices, processes or institutions. Similarly there is no clear definition of what constitutes good governance [4,5]. There is however a body of literature discussing what the elements of good governance should be focusing on issues such as inclusiveness, accountability, legitimacy, rule of law, and adaptability [4-9]. This discussion is outside the scope of this paper.

There, are a number of suggested definitions of governance, common for them is that governance includes both the institutions and processes of decision making, Two different aspects are emphasized; some emphasise the role of individuals and 
non-government organizations [10-12], others emphasise processes and institutions [13-15].

This paper focuses on the role of individuals, industry and organizations in the governance processes as well as the critical role that the government play in putting in place properly designed processes, institutions and laws that gives members of civil society the ability to make decisions regarding water management and allocation while protecting societal interest in socially and environmentally sustainable outcomes.

Individuals, industry, organizations and other parts of civil society have been involved in two main water governance processes. First, they have been involved in planning processes at the basin or regional level which includes setting parameters for water management and allocations such as defining water needs of the environment and various consumptive uses. In almost all jurisdiction such as the MIDB and the SSRB this has been in an advisory capacity developing draft plans which then has to be approved by a minister. Secondly, they have, through their individual decision making regarding water allocations and land resources, influenced water management and allocation. Individuals have bought and sold water allocations and thereby facilitated reallocation. They have made land and water management decisions which influence their water consumption and thereby also water availability and quality.

Governments have a critical role in both processes. In the planning processes they set the parameters under which civil society engage in these processes, who are involved, how are they resourced and supported, how can they make decisions, how can government departments engage in the process, and eventually, how is the advice being converted into final plans and actions? These are critical roles which will determine stakeholders' ability to effectively contribute to the governance process. Governments' role is also critical in introducing policies, laws and regulations which enables stakeholders to make efficient, timely and cost effective decisions about water management and allocation. Government must balance the role of market and regulation to ensure that the market, e.g. stakeholders' individual decisions, does not have detrimental third party impacts.

It is critical for successful governance outcome that these processes are adaptive to ensure that the rules and regulations governing both the planning processes and the individual decision making continue to evolve with experience, increased knowledge and environmental and societal changes.

\section{Evolution of governance in the Murray-Darling basin}

The Council of Australian Governments (CoAG) in 1994 agreed on a new water reform agenda which for the first time incorporated the two elements of water governance. By signing this agreement the states committed themselves, under fiscal penalties from the federal government, to implement these water reforms. Among other things: i) water charges should be set at full cost recovery prices to send appropriate economic signals to users to more carefully consider their water and land management decisions; ii) water entitlements should be unbundled from land and given clear specifications of ownership, transferability, reliability, and 
quality; iii) water markets should be introduced to allow water right to be traded among competing users, allowing individuals to make water allocation decisions; iv) specific entitlements should be given to the environment, acknowledging it as a legitimate water user; v) institutional reforms, including transfer of irrigation districts to bodies controlled by irrigators allowing them to make water management and allocation decisions; and vi) the community should be involved in water planning and education programs should be implemented to improve its ability to do so.

Subsequently, during the last half of the 1990s, most states introduced new water acts implementing these reforms, including a framework for water planning with community involvement. Ten years after the CoAG agreement the next step in water reform was taken when a National Water Initiative (NWI) was agreed on in 2004. It aimed to improve the ability of individuals to take water management and allocation decision by providing better frameworks for the two ways civil society engage in the governance processes. First, it set out to improve the operation of water markets by providing: i) better specified and nationally compatible water access entitlements, defined as shares of the available resource rather than in volumetric terms; ii) secure water entitlement registers, reducing transaction risks of individuals when making allocation decisions; and iii) national functioning water markets, including the progressive removal of barriers to trade to expand the ability of individuals to make allocation decisions. Second, it strengthened the public involvement in the water planning process and gave the plans more power by introducing: i) statutory-based water planning processes, defining the need of the environment and the size of the consumptive pool (the pool from which the access entitlements are ensured a share); ii) statutory provisions for environmental and other public benefits, and improved environmental management practices; and iii) a commitment to return all over overused systems to environmentally sustainable levels of extraction [16].

The planning processes started under the new State water acts and intensified after the 2004 NWI. In many catchments this resulted in significant proposed reductions in entitlements without compensation. This development took place in the middle of a ten years drought during the 2000s resulting in severe water shortages. Hence concern over the socioeconomic impact of these reductions in entitlements, especially in New South Wales (NSW), intensified and in 2006 NSW suspended its water sharing plans. In effect this constituted a formal deferral of the process of securing water for the environment via the planning processes [16].

Following the collapse of the planning approach various federal governments introduced a string of new National Strategies to secure water for the environment by purchasing water entitlements back from irrigators and investing in system efficiencies as well as introducing subsidies to influence individual farmers' water management and allocation decisions to improve their on-farm efficiency [16].

A number of other policies were also implemented to allow individual water users to participate more actively in the governance processes through their own individual water management and allocation decisions by increasing their ability to manage their water across seasons and operate more effectively in water markets. Carry over was introduced to allow water users to carry over unused 
allocations from one water year to the next subject to dam capacity. Some carry over has existed in some systems since the 1990s, but 2007-2008 was the first year it was available across the southern MDB states. Further a new concept of Spillable water accounts were introduced in 2010/11. This allowed irrigators to carry water over in excess of the announced carry over capacity. However, if the dams spill over, irrigators loose the water they have stored in this account. These arrangements provided irrigators with increased ability to use the markets to make allocation decisions to manage risk associated with uncertain supply between seasons.

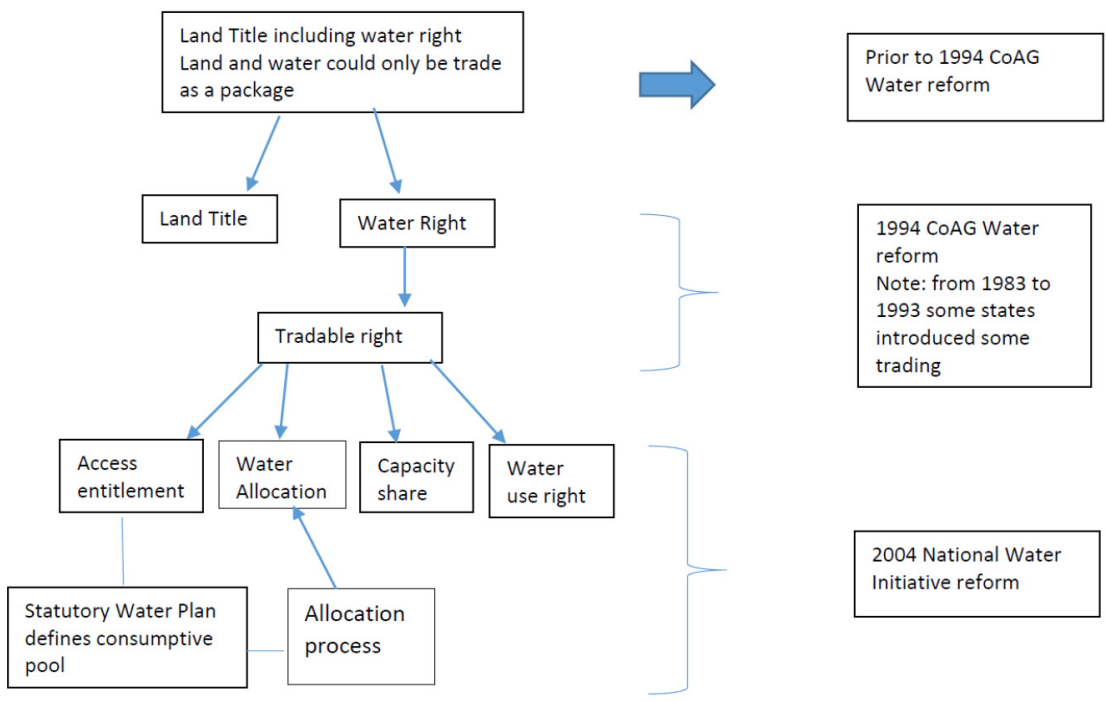

Figure 1: Unbundling of property rights in water and link to planning processes.

State governments have also been busy increasing the flexibility of individuals' ability to make allocation decision more effectively and timely using water markets, within sustainable boundaries set by the wider community, by further unbundling the water right (Figure 1). In the new world of unbundled water rights four different rights exist and an irrigators must control at least three of these rights to irrigate:

\section{1 Access entitlement}

This right entitles the holder to access a certain share of the consumptive pool as defined in the relevant water plan. Consequently, during the life of the plan this share has a volumetric value. However, once the plan is renewed the consumptive pool may be revised and change the volumetric value of the share. Hence, the system is adaptive as the consumptive pool can be regulated according to improved knowledge about the volume of water available in the source and the need of the environment. Each year the body managing the resource sets 
the seasonal allocation level which determines how big a proportion of the volume under the access entitlement that can be used. This level is set conservatively at the opening of the season depending on availability of water in the storages and is then revised during the season as availability increases. Again this is an adaptive process ensuring that total use stays within availability. An irrigator does not need to own an access entitlement to irrigate, provided s/he controls the following three rights.

\subsection{Water allocation account}

Once an allocation has been announced a volume of allocation water is credited to the allocation account of the entitlement holder. This water can then be used provided the holder of the allocation account has a capacity share to get it delivered and a water use right allowing the irrigator to apply the water. Each time the allocation level is revised additional water is credited to the account and as water is used or sold the volume is debited to the account. Conversely if the holder buys water in the allocation market it will be credited to the account. So this account functions much like a bank account for money. Any person can open a water allocation account and buy water and get it credited to the account. But again cannot use it unless $\mathrm{s} /$ he has the next two rights.

\subsection{Capacity share}

This right entitles the holder to get water delivered to the point where it is needed and is defined as a share of the delivery capacity of a particular system. There are two main reasons for unbundling this particular right. First, the fixed cost of maintenance is charged to the capacity share. Hence, when irrigators sell all or part of their access entitlement to somebody outside that delivery system, they are still responsible for paying their share of system maintenance. One of the main concerns over water trading among irrigators when trading was introduced was that some systems would be eroded through export of water leaving remaining irrigators with increasing cost. Hence it underpins the financial sustainability of the system. The second reason is that it allows irrigators to sell part or all of their access entitlement to improve their balance sheet, allow investment in farm infrastructure, paying off debt etc. while retaining the right to get water delivered. They can then continue to irrigate by buying allocation water when prices in that market is so that it is viable for them to irrigate, or buy back water entitlements if or when their financial position allows it. Hence, it improves individual irrigators' capacity to make allocation decisions.

\subsection{Water use right}

All water users need this right, to obtain it they need to demonstrate that they are using their water according to best practice, with minimum environmental impact. This is an important right as it alleviates environmental concern over potential negative impact of water moving to farmers with unsustainable practices or in sensitive locations where increased water use can have negative environmental impact. As such it has separated the issue of environmental assessment from the trading in both allocation water and access entitlements. 
Within this system of unbundled rights, individual's ability to make allocation decisions is very flexible and carried out within a framework developed involving civil society in defining fundamental issues about sharing available water between consumptive and non-consumptive uses. Access entitlements are now freely tradable between all people, and, as no right to use the water is attached, there is limited concern over this trade. Similarly trading in allocation water can take place relatively freely because, again, no right to use the water is associated with the trade. There however are some spatial restriction on allocation trading as it has to be possible to physically move the water from the region where the seller's allocation account is registered to the region where the buyer's account is registered.

Irrigators can also make allocation decisions to suit their individual cropping pattern, financial position, and attitude to risk. They can divest their access entitlement to reduce their debt and rely on seasonal purchases of allocation water when it is financially viable. Or, they can increase their access entitlement base by investing more money in that asset, enough to secure sufficient allocation water even during periods of drought. Some risk adverse irrigators with investments in permanent crops, with the potential of significant losses if insufficiently irrigated, might be interested in doing this. They can then sell excess allocation water during period of full supply.

In combination with carry over and spill-able water accounts these reforms have significantly allowed irrigators to actively participate in the governance processes through the individual allocation decisions they make and civil society has been given a voice in defining the boundaries within which this takes place.

\section{Experience with individuals making water allocation decisions}

Water trading within the MDB has increased significantly since it first started tentatively in South Australia and NSW in about 1984 and in Victoria in 1989. At that time land and water was still attached so administratively the water right was detached from the seller's land and immediately attached to the buyer's land. Bjornlund [17] and Bjornlund et al. [16] provided in-depth analysis of how water markets have been adopted and how the volume of trade has increased within Australia's largest Irrigation district the Goulburn-Murray Irrigation District (GMID) in Victoria. A thorough discussion is outside the scope of this paper and readers are referred to the above references as well as others for more detailed information. There are three main factors which have influenced the increase in market activity: i) governments introducing new policies and regulations easing restrictions on trade making it easier, faster and cheaper to trade as discussed above; ii) the increased level of water scarcity driven by drought and capping of water use for extractive purposes; and iii) the government entering the market to purchase access entitlements to meet environmental needs. Here we will briefly summarize how trade expanded and the importance that government played in this process by easing restrictions and entering the market: 
- Initially trading within the GMID was relatively restricted and cumbersome; hence during the first three years 1992-1994 less than one percent of irrigators traded in access entitlements each year and less than five percent traded in allocation water.

- In the mid-1990s restrictions were eased as trading was allowed between private irrigators and irrigators within irrigation districts and some spatial restrictions on trade between regions were eased. By then about $18 \%$ of irrigators bought and sold allocation water each year and $1.5 \%$ bought and sold entitlements.

- A further increase took place when trading was allowed to and from outside the GMID and the wine grape industry boomed after 1999. By 2004, 40-45\% of farmers were selling and buying allocation water and $2.5 \%$ were buying and selling entitlements. By 2004 more than $80 \%$ of all irrigators had participated in some kind of water trading.

- $\quad$ Trading in entitlement increased further with the government intervention in the market after 2008. We do not have the impact of that on market adoption but we have the impact on percentage of all entitlements trade discussed below.

- Reflecting the steady increase in the adoption or use of water markets the volume of both access entitlements and allocation water traded has also increased significant. It took ten years before the annual trade in access entitlements exceeded one percent of the entitlement base. However, since then it has increased significantly, especially driven by the government buying up water in the market but also by the easing of barriers to trade out of irrigation districts and the opening up of interstate trade. From 2003 to 2008 it increased to between three and five percent per year and exceed $10 \%$ by 2010/11.

- By now irrigators decisions in water markets have had a significant impact on how water is allocated. Over the first ten years $6.3 \%$ of all entitlements changed hand; however after 13 years about $20 \%$ of all entitlements had been traded. Since 2008-09 trade has accelerated strongly, driven primarily by the federal government starting to purchase entitlements in 2008 . So by now, who owns water entitlements is significantly influenced by individual irrigators' decisions rather than decisions made by governments.

- Similarly the market for allocation water has had a significant influence on who uses water each season as owners of allocation accounts trade their allocation water. By 2008, 25-40\% of all water used in the field during a given year was purchased in the market. After the introduction of carry-over and spill-able water this percentage has increased significantly. During 2010-2011 more water was bought in the market than was actually used. This reflect that irrigators purchased water at the close of one season in order to carry it over into the next season, so that they could start that year with a secure balance in their allocation account; thereby reducing the risk of seasonal fluctuations in supply and prices. 
- $\quad$ By now, irrigators decision making in both entitlement and allocation markets are having a significant impact on who owns and who uses water both in the long term and short term.

\section{Experience with public engagement in the planning processes}

The 1994 CoAG Water Reforms and subsequent new state legislation started the process of resolving over allocation and water sharing issues within planning processes involving key community stakeholder groups via catchment based water planning committees which in collaboration with representative from relevant government departments developed draft water sharing plans. The importance of these plans were further enhanced with the 2004 NWI giving them statutory status.

Planning processes therefor commenced in the MDB states during the late 1990s. In several regions of NSW these plans resulted in significant across the board reductions in irrigators' entitlements without any compensation and was therefore often associated with anxiety, heated debate and conflicts over how cuts should be implemented and who should carry the burden.

Analysing the process within the Naomi Valley of NSW Kuehne and Bjornlund [18] found that irrigators found that the process was unfair, confusing and frustrating. It left them feeling uncertain about their future as a consequence of a long drawn out process of first developing the plans as part of the CoAG reforms to a state where they were actually gazetted in 2002, to see them deferred in 2003 to be further developed to comply with the 2004 NWI. The implementation of these plans were then deferred again three years in a row due to ongoing community conflict and challenges. A number of issues were identified causing this frustration. There were evidence that stakeholders were led to believe that they were part of developing the Water Sharing Plans rather than providing advice. This was especially found frustrating when involved stakeholders read the plan produced by the government and found that it had no resemblance with the advice they had given and no argument was provided as to why the advice was not taken. Irrigators were also frustrated over the lack of support they were given and the involvement of government staff. They found that change of staff often took place during the process and that staff sympathetic to their views were removed from the process. They were also left with a feeling that scientific evidence and modelling were presented to support the government position rather than objective debate. This came to a head in one plan in a part of Queensland where the irrigators are large, financially strong and well organized. They hired their own independent experts and challenged the government's decisions. This resulted in an independent review which sided with the irrigators rather than the government, forcing it to revise its plan

\section{Change from planning to market process}

As discussed above the process of resolving water allocation issues and implementing uncompensated cuts to entitlements to meet environmental needs, 
through the planning processes ended in 2006 when NSW suspended their water sharing plans. This probably spurred the federal government to consider new options. In 2007 the Liberal government introduced a new National Plan for Water Security (NPWS), aimed at improving water use efficiency and recovering consumptive water rights through the markets to address the issue of over allocation and to meet environmental needs [19]. In late 2007, the Rudd Labour government took office. It largely retained the NPWS arrangements but increased its funding to 12.9 billion over ten years, and renamed it Water for the Future (WWF). Up to $\$ 3.1$ billion was budgeted for water purchases under the Restoring the Balance Program and a further $\$ 5.4$ billion for efficiency upgrades [20]. This saw a shift from resolving water reallocation issues and restoring the balance between extractive and non-extractive uses from the planning processes to the market processes while the planning process were still used to define the sustainable extraction levels and thus set the target for how much water needed to be bought back.

A new Commonwealth Water Act was also introduced in 2007. Its objective was to establish and enforce environmentally sustainable limits on water extraction, and provide the foundation for the creation of a Basin-wide environmental water plan and consolidate the individual state's water planning and trade mechanisms into a single over-arching framework.

The new Water Act also facilitated the creation of the Murray-Darling basin Authority (MDBA) consisting of a number of key stakeholders in the Basin. One of its core objectives was to develop a Basin Plan to restrict water extraction to more sustainable levels. The MDBA released the Guide to the proposed Basin Plan in 2010 . This guide proposed to further decrease diversions by $27 \%$ to $37 \%$ to secure a long-term average supply of environmental water of 3,000-4,000 GL [21]. When the Guide was presented to the affected communities for comments it was strongly opposed with irrigators in some regions burning copies of the guide to show their disgust. This send the MDBA back to the drawing board and it released its proposed plan in November 2011. Responding to community pressures the long term average recovery was revised to 2,750 GL [22]. Following the precedence from the NPWS and the WFF the reductions required to achieve this recovery would be purchased from willing sellers, with the federal government expected to fund the additional expenditure. Despite the fact that reductions now is full compensated they were still resisted and met with opposition from main stakeholder groups and caused conflicts between jurisdictions.

In November 2012, the federal Parliament passed the MDB Plan into law retaining the limited target for buy back of 2,750 GL to reach sustainable diversion limits. This outcome is to be achieved by 2019 with a performance review in 2015 [23]. As of March 31, 2013, water entitlements had been recovered with a long term average yield of 1,119GL for environmental under the Restoring the Balance Program [24]. The recovery effort was strengthened by the provision of an additional $\$ 1.77$ billion for strategic buyback within the MDB and to overcome environmental water delivery constraints along the river systems while the target for achieving this was postponed to 2024 The MDB Plan and the Australian process of water reform have been politically controversial, and occasionally 
resulted in conflicts between user groups [25] threatening efficient water reallocation across competing demands.

\section{Conclusions}

For governance to be successful in resolving water allocation and management challenges governments have to pursue two processes: i) develop flexible, and efficient institutions and mechanisms enabling individual members of civil society to make allocation and management decisions which influence water allocation and quality in a cost effective and timely manner; and ii) develop a framework which involves all elements of civil society in planning processes which defines the framework within which members of civil society can make individual management and allocations decisions in such a way that environmental and social outcomes are secured.

The Australian experience discussed in this paper illustrates the dynamic interaction between these two processes and stresses the need for government to take great care when designing, marketing and implementing institutions and instruments to facilitate and improve both processes. Both the planning and market processes in Australia have been associated with problems and conflicts but has been steadily moving forward due the severity of the problems and the willingness to pay increasing political and financial cost as the reform process has progressed. Combined with experiences from other jurisdictions this suggests that while the financial capability might be present in most developing countries to pay the transition cost associated with moving to the type of governance processes discussed in this paper the wiliness to pay the political cost is unlike to be there until scarcity problems reaches a certain level; at which both the political and financial cost is going to be very high, as Australia has experienced.

\section{References}

[1] World Economic Forum, 2014: Global Risks 2014. Geneva: World Economic Forum.

[2] Pahl-Wostl, C., Gupta, J., and Petry, D., 2008: Governance and the global water system: a theoretical exploration. Global Governance, 14, 419-435.

[3] Kaika, M., 2003: The Water Framework Directive: A new directive for a changing social, political and economic European framework. European Planning Studies, 11(3), 299-316.

[4] Lautze, J., De Silva, S., Giordano, M. and Sanford, 1. 2011: Putting the Cart before the Horse: Water Governance and IWRM. Natural Resources 35.

[5] De Löe, R, Armitage, C., Plummer, R., Davidson, S., and Moraru, L. 2009: From Government to Governance: A State-of-the-art Review of Environmental Governance. Guelph: Rob de Loe Consulting Services.

[6] Rogers, P. and Hall, A. 2003: Effective Water Governance. Stockholm, Sweden: Global Water Partnership.

[7] Hooper, B. 2010: River Basin Organization Performance Indicators: Application to the Delaware River Basin Commission. Water Policy 12 (4). 
[8] McCall, M, and Dunn, C. 2012: Geo-Information Tools for Participatory Spatial Planning: Fulfilling the Criteria for 'Good' Governance? Geoforum 43 (1).

[9] Biermann, F. 2007: Earth System Governance as a Crosscutting Theme of Global Change Research. Global Environmental Change 17 (3-4).

[10] United Nations Development Programme. 1997: Governance for Sustainable Human Development: UNDP Policy Document. New York: author.

[11] Tortajada, C. 2010: Water Governance: Some Critical Issues. International Journal of Water Resources Development 26 (2).

[12] Global Water Partnership. 2000: Integrated Water Resources Management. Stockholm, author.

[13] World Bank Group. 2011: Worldwide Governance Indicators. Washington: author.

[14] Alberta Water Council. 2008: Strengthening Partnerships: a Shared Governance Framework for Water for Life Collaborative Partnerships. Edmonton: Author.

[15] National Round Table on the Environment and the Economy. 2011: Charting a Course: Sustainable Water Use by Canada's Natural Resource Sectors. Ottawa: Author.

[16] Bjornlund, H.; Wheeler, S. and Rossini, P. 2013: Water Markets and Their Environmental, Social and Economic Impact in Australia. In Maestu, J. Ed. Water Trading and Global Water Scarcity: International Perspectives. UK: Francis Taylor.

[17] Bjornlund, H. "Increased participation in Australian water markets" WIT Transactions on Ecology and the Environment, Vol 96, WIT Press, 2006, ISSN 1743-3541, doi: 10.2495/SI060281.

[18] Kuehne, G. and Bjornlund, H. (2006): Frustration, Confusion and Uncertainty: Qualitative responses from Namoi Valley Irrigators. Water 33(3), 78-82.

[19] Howard, J. 2007: The National Plan for Water Security. Canberra, Prime Minister \& Cabinet.

[20] Wong, P. 2008: Water for the Future - Speech to the 4th Annual Australian Water Summit. Sydney Conference \& Exhibition Centre.

[21] MDBA. 2010: Guide to the proposed Basin Plan: Overview. Canberra: Author.

[22] MDBA. 2011. The Living Murray: Environmental water recovery progress report. Canberra: Murray-Darling Basin Authority. Canberra: Author.

[23] MDBA. 2012: Draft Basin Plan. Canberra: Author.

[24] DSEWPC. 2013: Progress of water recovery under the Restoring the Balance in the Murray-Darling Basin program. Canberra: Author.

[25] Young, M. in press: Designing water entitlement regimes for an everchanging and ever-varying future. Agricultural Water Management. 